\title{
Inflammatory and degenerative changes in the endometrium of mares of the Crioulo breed
}

\author{
Sandra M. Fiala', Claudi Alves Pimentel2, Anelise M. Hammes²; Silvia Ladeira ${ }^{3}$, Adriana K. Tarouco ${ }^{3}$ and Rodrigo C. Mattos ${ }^{4}$ \\ Morphology Department, Biology Institute-UFPel' ${ }^{1}$, Haras Santa Anita do Minuano, Pelotas ${ }^{2}$, College of Veterinary Medicine, UFPel ${ }^{3}$ and Reprolab-UFRGS ${ }^{4}$, RS, \\ Brazil
}

\begin{abstract}
Summary
In order to study the causes of infertility in mares of the Crioulo breed, we examined 960 mares served at pasture by 33 different stallions. At the end of the breeding season, open mares (118) were separated by rectal palpation (pregnancy rate of $87.7 \%$ ). Those mares were subjected to endometrial biopsy and uterine swab for bacteriological examination. Histologically, the endometria were classified in 4 grades according to Kenney and Doig (1986). Endometria classified as Grade I was observed in 49.2\% of the open mares, grade II in 33. 1\%, grade III in $12.7 \%$ and grade IV in 5.1\%. Severe inflammatory lesions were observed in 36/1 18 (30.5\%) cases and degenerative lesions in $16.9 \%$ of the endometrium (20/118). In the following breeding season, the pregnancy rate of mares with or without inflammation was 59.3 and $85.5 \%$ respectively $(\mathrm{P}<0.01)$ and the pregnancy rate of mares with or without degenerative lesions, 47 and $84.8 \%$, respectively $(\mathrm{P}<0.01)$. Old mares ( $>$ than 15$)$ had a significantly $(\mathrm{P}<0.001)$ lower pregnancy rate $(15 / 27,55.5 \%)$ than young $(=$ to or $<$ than 15$)$ mares $(54 / 61,88.5 \%)$. The frequency of inflammatory lesions was not significantly different $(P>0.8)$ among older and younger mares $(28.6$ vs. $31.0 \%$, respectively), however, degenerative lesions were more frequent $(P<0.001)$ in older mares than younger mares $(40.0$ vs. 7.0 $\%)$. We conclude that inflammatory and degenerative lesions are important causes of infertility in the Crioulo breed.
\end{abstract}

Keywords: endometritis / mares / endometrial biopsy / Crioulo Breed / reproduction

\section{Entzündliche und degenerative Veränderungen im Endometrium von Crioulo-Stuten}

Um die Ursachen der Infertilität bei Stuten der Rasse Crioulo zu untersuchen, wurden 960 Stuten untersucht. Die Bedeckung der Stuten erfolgte durch 33 verschiedene Hengste bei Weidehaltung. Am Ende der Zuchtsaison erwiesen sich 118 Stuten durch rektale Untersuchung als nicht tragend, was einer Trächtigkeitsrate von 87,7\% entspricht. Bei diesen Stuten wurden eine Endometriumbiopsie sowie ein Uterustupfer für die bakteriologische Untersuchung entnommen. Es folgte eine histologische Klassifizierung der Endometrien in vier Grade nach Kenney und Doig (1986). 49,2\% der Endometrien wiesen Grad I, 33,1\% Grad II, 12,7\% Grad III und 5,1\% Grad IV auf. Hochgradige entzündliche Alterationen wurden bei 36 von 118 Stuten (30,5\%) und degenerative Läsionen in 20 der 118 Endometrien (16,9\%) nachgewiesen. In der darauffolgenden Zuchtsaison erzielten die Stuten mit bzw. ohne Entzündungen eine Trächtigkeitsrate von 59,3\% bzw. 85,5\% $(P<0,01)$, diejenigen mit bzw. ohne degenerative Alterationen eine Trächtigkeitsrate von 47\% bzw. 84,8\% $(P<0,01)$. Stuten, die älter als 15 Jahre waren, wiesen eine signifikant $(P<0,001)$ geringere Trächtigkeitsrate $(15 / 27,55,5 \%)$ auf als jüngere Stuten $(\leq 15$ Jahre) $(54 / 61$, 88,5\%). Die Häufigkeit entzündlicher Alterationen war bei jüngeren und älteren Stuten nicht signifikant $(P>8)$ unterschiedlich $(28,6 \%$ bzw. $31,0 \%)$, wohingegen degenerative Läsionen bei älteren Stuten häufiger ( $P<0,001)$ vorkommt als bei jüngeren $(40,0 \%$ bzw. $7,0 \%)$. Zusammenfassend ist festzustellen, dass entzündliche und degenerative Alterationen eine wichtige Ursache für die Unfruchtbarkeit bei Stuten der Rasse Crioulo darstellt.

Schlüsselwörter: Endometritis, Stute, Endometriumbiopsie, Crioulo-Rasse, Reproduktion

\section{Introduction}

Wild horses are expected to have less reproductive problems than highly specialized breeds due to the natural selection that they are exposed and less influence of man. The Crioulo breed, although not wild nowadays, has been used for cattle management in the south of Brazil, Uruguay, Argentina and Chile. Lately competitive sports (rodeo) are using more and more animals of this breed due to their performance abilities. Consequently their economic value has increased and certain individuals are destined to breed regardless of any reproductive defect they may carry. Nowadays the Crioulo Association has more than 160 thousand registered horses belonging to 9,500 owners. Although with the growing interest for these horses, little information is available on its fertility. Data on reproductive performance in the breed is very scarce and infertility problems are reported on individual basis (Pimentel et al. 1997, Silva et al. 1996, Silva et al. 1995, Aver et al. 1992, Dowdall 1982). Endometritis is considered one of the most important causes of infertility in horses (Pimentel et al. 1997), however the participation of this disorder is unknown in the Crioulo breed.

The aim of this work was to study the occurrence and relationship of uterine inflammation and fibrosis on the fertility of mares of the Crioulo breed.

\section{Material an methods}

This work included 960 mares of the Crioulo breed, with ages ranging from 5 to 27 years old. The mares were managed under range conditions, and distributed in 6 farms and 33 groups of mares running with a single stallion. These farms were located in south Brazil.

The breeding season started in October and ended in April, when mares were examined by rectal palpation for preg- 
nancy diagnosis and those that were found open were subjected to a vaginal examination (recording presence or absence of inflammatory secretion), uterine culture (Conboy 1978) and endometrial biopsy (Kenney 1978). Mares found open were bred again in the following breeding season without any treatment, regardless of the results of the laboratory examination, in order to correlate the uterine status with the potential fertility (pregnancy rate).

Histologically, the endometria were classified in 4 grades based on inflammatory and degenerative changes (Kenney and Doig 1986). For statistical purposes mares were grouped into 2 classes: $0=$ negative or $1=$ positive.

The inflammatory score 0 (INFGROUP $=0$ ) was considered when no leukocytes were found or only a mild diffuse lymphocytic infiltration could be observed in the stratum compactum; besides the diffuse infiltration, a lymphocytic foci could be observed and accumulation of scattered lymphocytes or neutrophils were present in the stratum compactum. The inflammatory score 1 (INFGROUP $=1$ ) was considered when lymphocytes or neutrophils were present in a severe focal and/or diffuse fashion in the stratum compactum or, less frequently, in the stratum spongiosum; lymphocytes and neutrophils were present in abundance or in a widespread fashion or severe foci; widespread severe infiltration of the stratum compactum and some infiltration in the stratum spongiosum could also be observed.

The degenerative changes considered were glandular branches with cystic distention and periglandular fibrosis (one to three layers), fibrotic nests of glandular branches ("nests") and lymphatic lacunae (Kenney 1978). The degenerative scores were attributed when a subjective estimate under light microscopy with $100 \mathrm{X}$ magnification of the area of endome- trium affected by these changes. Score 0 (DEGROUP $=0$ ) were considered when less than $20 \%$ of the endometrium was affected (examining five fields per sample) and score 1 (DEGROUP $=1$ ) when more than $20 \%$ of the endometrium presented those changes.

Mares were divided into two groups: young (less than 15 years old) and old mares (equal to or older than 15 years old).

The effect of age on pregnancy rate was analyzed by linear regression. Chi square $\left(c^{2}\right)$ was used to evaluate the effect of inflammatory, degenerative lesions and age group on pregnancy rate.

\section{Results}

The pregnancy rate of 960 examined mares was $87.7 \%$ (842/960). The average frequency of open mares per farm was $12.5 \%$. The size of the herds varied from 3 to 89 mares and the pregnancy rate, from 50 to $100 \%$.

Only 3 of 118 mares found open presented purulent secretion on speculum examination and two had bacterial growth: one had Streptococcus zooepidemicus and the other Escherichia coli. Histologically, these two mares were included into INFGROUP 1

The frequency of inflammatory and fibrotic lesions observed in the uteri examined (118) is represented in table 1.

Pregnancy rate data in the following breeding season could be obtained in 96 of the 118 open examined. The effect of INFGROUP and DEGROUP in fertility can be seen in table 2.

Table 1 Frequency of uteri with degenerative or inflammatory lesions in 118 open mares / Häufigkeit degenerativer oder entzündlicher uteriner Läsionen bei 118 nicht tragenden Stuten

\begin{tabular}{lcc}
\hline & Number of cases & $\%$ \\
\hline WITH INFL & $36 / 118$ & 30.5 \\
WITH FIBROSIS & $20 / 118$ & 16.9 \\
\hline
\end{tabular}

Table 2 Pregnancy rate as affected by inflammatory or degenerative lesions / Trächtigkeitsrate in Abhängigkeit von entzündlichen oder degenerativen Läsionen

\begin{tabular}{|c|c|c|}
\hline & Number of cases & Pregnancy rate $\%$ \\
\hline INFGROUP 0 & $69 / 96$ & $85.5^{a}$ \\
\hline INFGROUP 1 & $27 / 96$ & $59.3^{b}$ \\
\hline DEGROUP 0 & $79 / 96$ & $84.8^{a}$ \\
\hline DEGROUP 1 & $17 / 96$ & $47.0^{b}$ \\
\hline
\end{tabular}

$\overline{a, b}$ Columns with different superscripts differ $\mathrm{P}<0.01$

Table 3 Frequency of endometrial biopsy grade and subsequent pregnancy rate in the following breeding season / Häufigkeit der histologische Graduierung anhand einer Endometriumbiopsie und entsprechende Trächtigkeitsrate in der nächsten Zuchtsaison

\begin{tabular}{ccccc}
\hline Grade & Frequency of grades & $\%$ & Pregnancy rate & $\%$ \\
\hline I & $58 / 118$ & 49.2 & $48 / 96$ & $87.5^{\mathrm{a}}$ \\
II & $39 / 118$ & 33.1 & $29 / 96$ & $82.8^{\mathrm{ab}}$ \\
III & $15 / 118$ & 12.7 & $13 / 96$ & $61.5^{\mathrm{bc}}$ \\
IV & $6 / 118$ & 5.1 & $6 / 96$ & $16.7^{\mathrm{d}}$ \\
\hline
\end{tabular}

\footnotetext{
${ }^{a, b}$ Columns with different superscripts differ $\mathrm{P}<0.005$
} 
Table 4 Regression analysis biopsy grade and age on pregnancy rate and age on biopsy grade of the mares / Regressionsanalyse: Einfluss von histologischem Grad und Alter auf die Trächtigkeitsrate und Einfluss des Alters auf den histologischen Grad der Stute

\begin{tabular}{|c|c|c|c|c|c|}
\hline Dependent variable & Intercept & Coefficient & Independent variable & $\alpha$ & $R^{2}(\%)$ \\
\hline Pregnancy Rate & 1.08579 & -0.165 & Biopsy Grade & $\mathrm{P}<0.001$ & 14.0 \\
\hline Pregnancy Rate & 1.13712 & -0.026 & Age & $P<0.001$ & 14.7 \\
\hline Biopsy Grade & 1.25538 & 0.038 & Age & $P<0.001$ & 6.4 \\
\hline
\end{tabular}

Table 5 Frequency of degenerative (DEGROUP 1) and inflammatory lesions (INFGROUP 1) in the endometrium of young and aged mares / Häufigkeit von degenerativen (DEGROUP 1) und entzündlichen Läsionen (INFGROUP 1) im Endometrium junger und alter Stuten

\begin{tabular}{|c|c|c|c|c|}
\hline \multirow[b]{2}{*}{ Young mares } & \multicolumn{2}{|c|}{ DEGROUP 1} & \multicolumn{2}{|c|}{ INFGROUP 1} \\
\hline & $5 / 71$ & $7.0 \%^{a}$ & $22 / 71$ & $31.0 \%^{\mathrm{a}}$ \\
\hline Old mares & $14 / 35$ & $40.0 \%{ }^{b}$ & $10 / 35$ & $28.6 \%^{a}$ \\
\hline
\end{tabular}

${ }^{a, b}$ Columns with different superscripts differ $\mathrm{P}<0.001$

The frequency of endometrial biopsy grades among examined mares (1 18 mares) as well as the pregnancy rates in the following year (96 mares) is reported in table 3 .

Regression analysis $(\mathrm{P}<0.01)$ showed that pregnancy rates tend to decrease as the biopsy grade, the score of endometrial fibrosis and age increases (Table 4). It can also be observed in this table that the biopsy grade and the score of endometrial fibrosis increase in a linear fashion as the mares aged.

Bacteriological data were obtained from 111 of the 118 endometrial swabs collected. Bacterial growth resulted from 26 (23.4\%) samples. The most frequent agents found were: Streptococcus zooepidemicus in 3 (11.8\%), Escherichia coli in $3(11.8 \%)$ and Acinetobacter spp in 3 (11.8\%). The other organisms were Corynebacterium spp 2 (7.7\%), Staphylococcus aureus 1 (3.8\%), Enterobacter spp 1 (3.8\%).

Bacterial growth was observed in 24/79 (30.4\%) of the endometria without inflammatory lesions and in just 2/32 (6.3\%) of the mares with significant inflammation of the endometria had bacterial growth $(\mathrm{P}<0.01)$. There was no relationship $(P>0.4)$ between degenerative changes and bacterial growth

Old mares ( $>$ than or equal to 15) had a significantly $(P<0.001)$ lower pregnancy rate $(15 / 27,55.5 \%)$ than young (= to or $<$ than 15$)$ mares $(54 / 61,88.5 \%)$. The frequency of fibrosis (DEGROUP 1) was significantly higher in old mares, but inflammatory lesions (INFGROUP 1) were not different among age groups (Table 5).

\section{Discussion}

The overall pregnancy rate in this study $(87.7 \%)$ is similar to the data reported by several authors and other breeds (Collery 1974, Hutton and Meacham 1968, Ricketts and Young 1990, Laing an Leech 1975) for free running horses exposed to a stallion during the breeding season. Four stallions had a pregnancy rate lower than $70 \%$. If we remove these four stallions from the calculations the pregnancy rate would increase from $87.7 \%$ to $91 \%$. This fact must to be considered since the stallions were free running with the mares and a breeding soundness examination was not performed. This fact indicates that besides the mares, the stallion plays an important role in the overall pregnancy rate.
According to Rowlands (1981), in hand mated horses fertility is reported to be slightly lower (60\%). There are two possible reasons for the lower fertility of hand-mated horses:

hand-mated horses are selected for conformation or athletic performance leaving fertility in a secondary plane of importance, while mares bred at pasture are subjected to natural selection and population of fertile animals grows faster than sub-fertile;

hand breeding usually begins in late winter and ends by mid summer, while pasture bred horses are less affected by man's decisions about the time they should be, respecting natural seasonality what increases the chances of mares becoming pregnant.

Even though the pregnancy rate of $87.7 \%$ could be considered high, the uterine disorders observed among the mares that fail to conceive under natural conditions is also similar to the frequencies reported for other breeds (Kenney 1978, Kenney and Doig 1986, Gordon and Sartin 1978). Table 3 shows the frequencies of endometrial biopsies grades. As it is shown in Table 1, 30.5\% of the non-pregnant mares of the Crioulo breed, had inflammation in the endometrium and $16.9 \%$ had uterine fibrosis. In Table 2, it can be observed the reproductive performance of these mares in the following breeding season. The pregnancy rate of mares with significant inflammatory lesions in the endometrium was $59.3 \%$ compared with $85.5 \%$ in mares without inflammatory lesions. It can be speculated that many mares resolve the endometritis by their natural defense mechanisms during the resting period between the breeding seasons or that the degree of endometrial inflammation has a limited effect on fertility.

Fibrotic lesions of the endometrium had more dramatic effects on fertility than inflammatory lesions. Only $47 \%$ of the mares included in the group with significant degenerative lesions became pregnant in contrast of $84.8 \%$ in the group without these lesions (Table 2).

Using the classification of Gordon and Sartin (1978) and Kenney and Doig (1986), into four endometrial biopsy grades, the frequency of mares that fall into grades I, II, III and IV were 49.2, 33.1, 12.7 and 5.1\%. This shows that a great majority of barren mares fall into the normal group (grade I) or into discrete endometrial lesion (grade II). There was a significant trend $(P<0.001)$ to a decrease in fertility in the next 
breeding season as the biopsy increases (Table 4). This observations agrees with previous studies (Kenney 1978, Gordon and Sartin 1978) showing the practical application of the endometrial biopsy to predict the potential fertility of mares.

This work shows that Crioulo breed has as other breeds like the Thoroughbred 10 to $37 \%$ of endometrial problems (Asbury 1986).

There were only 3 of the 118 open mares that showed clinical signs of endometritis upon speculum examination (purulent secretion coming out of the cervix and laying down on the floor of the vagina). From two of 3 mares, bacteria were isolated (Streptococcus zooepidemicus and Escherichia coli). In the following breeding season none of those 3 mares became pregnant. Although the severity of the uterine discharge, the usefulness of the procedure (vaginal examination) for diagnosing endometritis is very limited, since only 3 of $36(8.3 \%)$ cases of histological inflammatory lesions of the endometrium showed clinical signs. However, the importance of clinical examination was demonstrated since none of the mares with clinical signs became pregnant in the following breeding season. On the other hand if one considers just the clinical information $92.7 \%$ of the cases with histological inflammation will be missed. This would stress the limitation of the procedure and it has to be considered that during clinical examination there is a higher proportion of mares in the luteal phase of the cycle, when cervix is closed and no secretion would come out from the uterus (Kenney 1978, Le Blanc 1993).

The most frequent bacteria isolated (1 1.8\%) were Streptococcus zooepidemicus and Escherichia coli, that agrees with most of the foreign literature (Asbury 1986, Conboy 1978, Wingfield-Digby and Rickets 1982, Le Blanc 1993) and local reports (Amaral et al. 2007, Mattos et al. 1984).

A great proportion of the mares with endometritis have other causes than bacterial (Caslick 1937, Pimentel et al. 1997, Amaral et al. 2007). In 79 mares without inflammation or with mild lesions, 24 (30.4\%) had bacterial growth. Similar result was observed by Doig and Waelchi (1993) who found inflammatory reaction in just 18\% of the mares with positive culture. This data indicates that potential pathogens can be harvested from uteri of normal mares (Kenney 1978, Amaral et al. 2007)

As the mares ages there is a trend to increase the score of degeneration (Kenney 1978, Held and Rohrbach 1991) and to present reduced fertility (Held and Rohrbach 1991; Vanderwall et al. 1989). These results shows that age effects significantly the fertility of the Crioulo breed and the age of mares older than 15 had a significantly $(P<0.0001)$ lower pregnancy rate $(55.6 \%)$ than mares younger than 15 (88.5\%). Based on this result it can be recommended that Crioulo mares older than 15 must receive a special attention in order to have an acceptable reproductive performance.

Aged mares had $(P<0.0001)$ higher frequency of fibrotic lesions of the endometrium DEGROUP 1 (40\%) than in young $(7 \%)$, which would be an expected result, however there is no information about the aging and fertility in the Crioulo breed. The breed is claimed to be rough due to natural selection process to which it was exposed during decades in southern part of South America (Dowdall 1982) and a higher longevity would be expected. The lower fertility of mares older than 15 is similar to what happens in other breeds (Held and Rohrbach 1991, Vanderwall et al. 1989) as reported for the Thoroughbred (Ricketts and Young 1990, Loy 1980).

Inflammatory lesions were not associated with age as it had been previously reported in other breeds (Kenney 1978, Kenney 1993). The reasons for these results are not clear. New studies are recommended with larger number of animals. The lower fertility of old mares can be attributed to fibrotic and not inflammatory lesions of the endometrium.

It can be concluded that the Crioulo breed has similar endometrial lesions as that reported for other breeds and the fertility of the affected mares is significantly reduced when compared to normal mares. Aging process increases degenerative lesions of the endometrium and reduces fertility in the Crioulo breed.

\section{References}

Amaral M., Pimentel C A, Meirelles M., Fiala S. M. E., Schramm R, Xavier E. and Mendoca M . (2007) Endometrite equina: fungos e bacterias. Archivos de Zootecnia (Universidad de Córdoba) 56, 875-884

Asbury A. C. (1986) Endometritis in the mare. In: Morrow D. A., Current Therapy in Theriogenology, Philadelphia, W. B. Saunders Company. 1143

Aver G. P., Goncalves R., Xavier S., Magalhaes Neto A., Santos P. F. M. and Pimentel C. A. (1992) Características bacteriológicas do útero de éguas abatidas em Pelotas - RS. In: VIII Encontro de Pesquisa Veterinária - Anais. Pelotas. 15 abstr.

Bennett D. G. (1987) Diagnosis and treatment of equine bacterial endometritis. J. Equine Vet. Sci. 7, 345-352

Bristol F. (1987) Fertility of pasture bred mares in synchronized oestrus. J.Reprod. Fert. (Suppl.) 35, 39-43

Carnevale E. and Ginther O. J. (1992) Relationship of age to uterine function and reproductive efficiency in mares. Theriogenology 37, $1101-1105$

Caslick E. A. (1937) The vulva and the vulvo-vagina orifice and its relation to genital health of the Thoroughbred mare. Cornell Vet. 27, 178-187

Collery L. (1974) Observations of equine animals under farm and feral conditions. Equine Vet. J. 6, 170-173

Conboy H. S. (1978) Diagnosis and therapy of equine endometritis. Proc. Am. Assoc. Equine Pract. 165-171

Dascanio J., William B. L. and Bowen J. M. (1997) How to perform and interpret uterine citology. Proc. Am. Assoc. Equine Pract. 43, 182-187

Doig P. A. and Waelchi R. O. (1993) Endometrial biopsy. In McKinnon A. O. and Voss J. L. (Eds.) Equine Reproduction. Philadelphia: Lea \& Febiger. 225-233.

Doig P. A., McKnight J. D. and Miller R. B. (1981) The use of endometrial biopsy in the infertile mare. Can. Vet. J. 22, 72-76

Dowdall R. C. (1982) Criando Criollos Buenos Aires, Ed. Hemisfério Sur, 409

Gordon L. R. and Sartin E. M. (1978) Endometrial biopsy as an aid to diagnosis and prognosis in equine infertility. J. Eq. Med. Surg. 2, 328-336

Held J. P. and Rohrbach B. (1991) Clinical significance of uterine biopsy results in the maiden and non-maiden mare. J. Reprod. Fert. (Suppl) 44, 698-699

Hughes J. P. and Loy R. G. (1969) Investigations on the effect of intrauterine inoculations of Streptococcus zooepidemicus in the mare. Proc. Am. Assoc. Equine Pract. 289-292 
Hutton C. A. and Meacham T. N. (1968) Reproductive efficiency on fourteen horse farms. J. Anim. Sci. 27, 434-438

Kenney R. M. (1993) Chronic Degenerative endometritis (CDE) .Proc. of the John Hughes Intern Workshop on Equine Endometritis. Equine Vet. J. 25, 186

Kenney R. M. and Doig P. A. (1986) Equine endomterial Biopsy In: Morrow D. A. Current Therapy in Theriogenology. Philadelphia W.B. Saunders, 723-729

Kenney R. M. (1978) Cyclic and pathological changes of the mare endomterium as detected by biopsy with a note on early embryonic death. J. Am. Vet. Med. Assoc. 172, 241-262

Laing J. Á. and Leech F. B. (1975) The frequency of infertility in Thoroughbred mares. J. Reprod. Fert. 23, 307-310

LeBlanc M. M. (1993) Vaginal Examination. In: McKinnon A. O. and Voss J. L. (Eds.) Equine Reproduction. Philadelphia: Lea \& Febiger, $221-224$

Lehmann J., Ellenberger C., Hoffmann C., Bazer F. W., Klug J., Allen W. R., Sieme H. and Schoon H. A. (2011) Morpho-functional studies regarding the fertility prognosis of mares suffering from equine endometrosis. Theriogenology 76, 1326-1336

Loy R. G. (1980) Characteristics of postpartum reproduction in mares. Vet. Clin. North Amer. Large Anim. Pract. 2, 235-359

Mattos R. C., Mattos A. L. G., Klug E. and Günzel A. R. (1984) Citologia endometrial na égua auxiliar e complementar. Rev. Bras. Reprod. Anim. 8, 83-90

Pimental C. A., Hammes A. M., Fiala S. M., Ldeira S. L. and Aver G. (1997) Endometrites em Éguas da Raça Crioula. In: XI Congresso Estadual de Medicina Veterinária. Anais. Gramado - RS. 239

Ricketts S. W. and Mackintosh M. E. (1987) Role of anaerobic bacteria in equine endometritis. J. Reprod. Fert. (Suppl) 35, 343-351,

Ricketts S. W. and Young A. (1990) Thoroughbred mare fertility. Vet Rec. 126, 68, 1990

Ricketts S. W., Young A. and Medici E. B. (1993) Uterine and clitoral cultures. In McKinnon A. O. and Voss J. L. (Eds.) Equine Reproduction. Philadelphia: Lea \& Febiger. 234-245

Rowlands I. W. (1981) Perspectives in perissodactyls. Equine Vet. J. 13, 85-87

Ruiz-Pesini E., Diez C., Lapeña C. A. C., Perez-Martos A., Montoya J., Alvarez E., Arenas J. and Lopez-Perez M. J. (1998) Correlation of sperm motility with mitochondrial enzymatic activities. Clin. Chem. 44, 1616-1620

Schoon H. A. and Schoon D. (2003) The category I mare (Kenney and Doig 1986): expected foaling rate $80-90 \%$ - fact or fiction? Pferdeheilkunde 19,698-701
Silva C. A. M. (1983) Uma nova técnica para a correção cirúrgica da pneumovagina na égua. Turf e Fomento, 247-248

Silva G. B., Brum D., Ribeiro G. A., Neto A. M., Pimentel C. A., Santos P. F. M., Hammes A. M., Rodrigues R. F. and Xavier S. (1996) Bactérias Aeróbicas nas endometrites em eqüinos - Pelotas - RS. In: V Congresso de Iniciação Científica UFPel, UCPel e FURG, Anais. Pelotas-RS, 180

Silva G. B., Ribeiro G. A., Hammes A. M., Pimentel C. A., Santos P. F. M., Xavier S., Rodrigues R. F. and Brum D. S. (1995) Bactérias isoladas de úteros de eqüinos abatidos em matadouro In: V Congresso de Iniciação Científica UFPel, UCPel e FURG, Anais... Rio Grande, 149 abst.

Stee/ R. D. G. and Torrie J. H. (1960) Principles, Procedures of Statistics. New York: McGraw-Hill Book Company, Inc., 481

Threlfall W. (1984) Introduction: Intrauterine infection in mares. Proc. Symposium on Mare Infertility. Western States Veterinary Conference, Las Vegas, Nevada, 5-7

Solanet E. (1946) Tratado de hipotecnia, Buenos Aires, Ed. Morata, 401

Van Rensburg S. W. J. and van Heerden J. S. (1953) Infertility in mares caused by ovarian dysfunction. Onderstpoort J. Vet. Res. 26, 285-313

Vanderwall D. K., Peyrot L. M., Weber J. Á.and Woods G. L. (1989) Reproductive efficiency of the aged mare. Proc. Ann. Meet. Theriogenology, Coeur d' Alene, 153-156

$\operatorname{Vaz}$ A. K., Risch A. L. C. and Brendler R. (1979) Infecções genitais em éguas na região de Bagé, RS. Turf \& Fomento, março/abril, 102-103

Wingfield-Digby N. J. and Ricketts S. W. (1982) Results of concurrent bacteriological and cytological examinations of the endomterium of mares in routine stud farm practice 1978-1981. J. Reprod. Fert. (Suppl) 32, 181-185

Sandra Mara Fiala

Morphology Department

Biology Institute

CEP: $96020-700$

Centro - Pelotas-RS

Brasil

sandrafiala@yahoo.com.br 